\title{
Penggunaan Mulsa Vertikal pada Lahan Kering untuk Menekan Erosi, Aliran Permukaan dan Pengaruhnya terhadap Pertumbuhan dan Produksi Jagung
}

Using vertical mulch to upland for reducing erosion, runoff and its responses to maize growth and yields

\author{
Dewa O. Suparwata ${ }^{1}$, Nurmi $^{2}$, Moh. Ikbal Bahua ${ }^{2}$ \\ ${ }^{1}$ Mahasis wa Program Studi Agroteknologi Fakultas Pertanian Universitas Negeri Gorontalo \\ Jl. Jend. Sudirman No. 6 Kota Gorontalo 96128 \\ ${ }^{2}$ Staf Pengajar Program Studi Agroteknologi Fakultas Pertanian Universitas Negeri Gorontalo \\ Jl. Jend. Sudirman No. 6 Kota Gorontalo 96128 \\ $\square: \underline{\text { ummyhafiz@ung.ac.id }}$
}

Diterima 27 September 2012/Disetujui 20 November 2012

\begin{abstract}
This study aimed to determine the effect of vertical mulching to minimize of runoff and soil erosion, vertical mulching influence on the growth and yield of maize, and the correlation between erosion and runoff to maize yield in vertical mulching. This study was conducted in March and July 2012 in the village of Bulontala, District of South Suwawa, Bolango Bone regency, Gorontalo province with slope $+15 \%$. This study uses a randomized block design (with three treatment levels: (a) P0 control, (b) P1 (vertical mulching with length $1 \mathrm{~m}$, width $0.5 \mathrm{~m}$ and the $0.4 \mathrm{~m}$ ), and (c) P2 (vertical mulch with $1 \mathrm{~m}$ long, $0.5 \mathrm{~m}$ wide and $0.5 \mathrm{~m} \mathrm{in}$ ). Each treatment was repeated 3 times in order to obtain experimental plots 9 unit. Observation parameters include surface runoff, erosion, plant growth and the production of maize. Data was analyzed using analysis of variance with the help of SAS data processing program. P1 treatment because runoff and soil erosion are markedly lower (surface flow of $108.19 \mathrm{~m} 3 \mathrm{ha}-1$ and the erosion of $683.0 \mathrm{~kg}$ ha-1). P1 treatment significantly affected the growth of stem diameter $(2.21 \mathrm{~cm})$ and increased production of dry shelled maize crop (3.28 ton ha-1). Surface flow is positively correlated with erosion and runoff and erosion negatively correlated with maize production.
\end{abstract}

Keywords: Mulching, dry land, surface runoff, erosion, maize

\section{PENDAHULUAN}

Kegiatan budidaya tanaman pertanian, pada prinsipnya harus didasarkan pada penerapan konservasi tanah dan air khususnya pada lahan kering berlereng, karena dengan menerepkan teknik konservasi kehilangan lapisan tanah yang akan membawa bahan organik dan unsurunsur hara yang terkandung di dalam tanah dapat teratasi dan kerusakan tanah dapat diminimalisir. Lahan kering didefinisikan sebagai hamparan lahan yang tidak pernah tergenang atau digenangi air pada sebagian besar waktu dalam setahun atau sepanjang waktu (Dariah et al., 2004). Berdasarkan letaknya di atas permukaan laut (dpl), lahan kering di Indonesia dapat dibagi menjadi dua kelompok: (1) lahan kering dataran rendah, yaitu lahan kering yang letaknya $<700 \mathrm{~m} \mathrm{dpl,} \mathrm{dan} \mathrm{(2)} \mathrm{lahan} \mathrm{kering} \mathrm{dataran} \mathrm{tinggi,} \mathrm{yang} \mathrm{terletak} \mathrm{antara} 700$ dan $2500 \mathrm{~m}$ dpl (Santoso, 2003). Pada umumnya lahan kering memiliki tingkat kesuburan tanah yang rendah, terutama pada tanah-tanah yang tererosi, sehingga lapisan olah tanah menjadi tipis dan kadar bahan organik rendah. Secara alami kadar bahan organik tanah di daerah tropis cepat menurun, mencapai $30-60 \%$ dalam waktu 10 tahun (Suriadikarta et al., 2002 dalam Abdurachman et al., 2008). Keterbatasan air pada lahan kering mengakibatkan usahatani tidak dapat dilakukan sepanjang tahun, dengan indeks pertanaman (IP) kurang dari 1,50. Penyebabnya antara lain adalah distribusi dan pola hujan yang fluktuatif, baik secara spasial maupun temporal (Abdurachman et al., 2008). 
Topografi tanah di Provinsi Gorontalo sebagian besar adalah perbukitan BPS Provinsi Gorontalo (2011). Oleh karena itu, karakteristik lahan di Provinsi Gorontalo didominasi oleh lahan-lahan miring. Keadaan tersebut sangat mengkhawatirkan dengan perilaku petani yang tidak menerapkan teknik konservasi tanah dan air, karena kurangnya pengetahuan dan modal yang dimiliki. Keadaan demikian akan mengakibatkan sangat rentan terjadinya aliran permukaan dan erosi tanah dalam skala yang besar. Aliran permukaan adalah air yang mengalir di atas permukaan tanah atau bumi. Bentuk aliran inilah yang paling penting sebagai penyabab erosi (Arsyad, 2006). Aliran permukaan mengakibatkan kehilangan bahan yang terlarut (unsur hara, pupuk, dan pestisida) maupun yang terangkut berupa bahan organik dan bahan mineral halus (liat dan debu) serta mikroba yang dapat mencemari lingkungan yang dilewati (Brata, 2004).

Wibowo et al., (2007), mendefinisikan erosi sebagai suatu proses dimana tanah dihancurkan dan kemudian dipindahkan ke tempat lain oleh kekuatan air, angin atau gravitasi. Erosi dan sendimentasi yang diakibatkan oleh air hujan atau aliran air, terdiri dari 3 proses utama, yaitu: pelepasan (detachment), pemindahan (transportation), dan pengendapan (deposotion) (Hardiyatmo, 2006). Dampak dari erosi menyebabkan hilangnya lapisan tanah yang subur dan baik untuk pertumbuhan tanaman serta berkurangnya kemampuan tanah untuk menyerap dan menahan air (Arsyad, 2006). Upaya mengurangi lajunya aliran permukaan dan menurunkan erosi tanah dapat dilakukan dengan penerapan teknologi mulsa vertikal.

Mulsa vertikal merupakan teknik penggunaan mulsa dengan cara memasukkan sisa tanaman ke dalam rorak atau alur yang dibuat mengikuti kontur (Noeralam et al., 2003). Ukuran jebakan mulsa harus disesuaikan dengan keadaan lahan dengan lebar 0,40-0,60 $\mathrm{m}$ dan dalam 0,30-0,50 m. Jarak antar barisan jebakan mulsa ditentukan oleh kemiringan lahan atau berkisar antara 3-5 m (Subagyono et al., 2004). Hasil penelitian Pratiwi (2001) menunjukkan perlakuan mulsa vertikal yang ditempatkan dibagian hilir individu tanaman menghasilkan aliran permukaan lebih rendah $(161,58 \mathrm{~mm})$, mulsa vertikal dengan jarak antara saluran 6 meter $(162,69 \mathrm{~mm})$, dibandingkan dengan kontrol $(438,10 \mathrm{~mm})$. Selanjutnya Nurmi (2012) menunjukkan mulsa vertikal $\mathrm{P}_{1}$ menghasilkan erosi yang lebih rendah $\left(1,02\right.$ ton $\left.\mathrm{ha}^{-1}\right)$, dibandingkan dengan tanpa mulsa vertikal $\mathrm{P}_{0}\left(3,47\right.$ ton ha' $\left.{ }^{-1}\right)$.

Penerapan teknologi mulsa vertikal memberikan keunggulan yakni: meningkatkan kesuburan tanah karena menambah bahan organik, meningkatkan peresapan air, mengurangi erosi, meningkatkan kehidupan jasad mikro dan makro di dalam tanah, dan meningkatkan kelembaban tanah (Ruijter dan Agus, 2004). Penelitian ini bertujuan untuk mengetahui pengaruh mulsa vertikal dalam menekan aliran permukaan dan erosi tanah, pengaruh mulsa vertikal terhadap pertumbuhan dan produksi jagung, dan mengetahui korelasi antara aliran permukaan dengan erosi serta korelasi aliran permukaan dan erosi dengan produksi pada penggunaan mulsa vertikal.

\section{BAHAN DAN METODE}

Penelitian ini dilaksanakan pada Bulan Maret sampai Juli 2012, bertempat di Desa Bulontala, Kecamatan Suwawa Selatan, Kabupaten Bone Bolango, Provinsi Gorontalo, dengan kemiringan lereng yakni $\pm 15 \%$. Alat yang digunakan dalam penelitian di lapangan meliputi: cangkul, linggis, skop, sabit, bak penampung, drum, plastik transparan, pipa paralon, dan meteran. Sedangkan alat yang digunakan untuk analisis di laboratorium yaitu: timbangan analitik, petridis, oven, desikator, kertas saring watma 42. Bahan yang digunakan pada penelitian lapangan yaitu: mulsa (berasal dari mulsa jagung), benih jagung, pupuk, dan pestisida. Sedangkan bahan yang digunakan di laboratorium ialah: sampel sedimen (100 g) dan sampel aliran (100 ml).

Penelitian ini merupakan penelitian yang dilakukan di lapangan. Ukuran tiap petak percobaan ialah $9 \mathrm{~m}$ x $5 \mathrm{~m}$. Mengunakan rancangan acak kelompok (RAK), dengan 3 taraf perlakuan, yaitu: 
a. Kontrol $\left(\mathrm{P}_{0}\right)$

b. Perlakuan mulsa vertikal dengan Panjang $1 \mathrm{~m}$, lebar $0,5 \mathrm{~m}$ dan dalam $0,4 \mathrm{~m}\left(\mathrm{P}_{1}\right)$

c. Perlakuan mulsa vertikal dengan Panjang $1 \mathrm{~m}$, lebar $0,5 \mathrm{~m}$ dan dalam $0,5 \mathrm{~m}\left(\mathrm{P}_{2}\right)$

Setiap perlakuan di ulang sebanyak 3 kali, sehingga diperoleh 9 unit petak percobaan.

Parameter pengamatan dalam penelitian ini meliputi: aliran permukaan, erosi, pertumbuhan, dan produksi tanaman jagung. Analisis data dilakukan dengan Analisis Of Varians (Anova) menggunakan program pengolah data SAS. Jika $\mathrm{F}$ hitung lebih besar dari $\mathrm{F}$ tabel maka dilakukan uji lanjut BNT 5\%. Untuk melihat hubungan antara aliran permukaan dengan erosi terhadap sifat fisik tanah maka dilakukan analisis korelasi.

\section{Aliran Permukaan dan Erosi Tanah}

\section{HASIL DAN PEMBAHASAN}

Aliran permukaan merupakan aspek penting dalam terjadinya erosi tanah. Semakin besar aliran permukaan, maka erosi yang ditimbulkannya semakin besar pula begitu juga sebaliknya. Aliran permukaan terjadi apabila masa tanah tidak mampu lagi menahan air yang turun ketika hujan. Aliran permukaan akan berjalan cepat apabila lahan tidak memiliki vegetasi sebagai penutup permukaan tanah, sehingga erosi yang ditimbulkan lebih besar. Analisis sidik ragam menunjukkan bahwa mulsa vertikal berpengaruh nyata terhadap aliran permukaan dan erosi tanah. Rata-rata volume aliran permukaan dan erosi tanah dengan hasil uji lanjut BNT $(\mathrm{P}<0,05)$ disajikan dalam Tabel 1.

Tabel 1. Rataan volume aliran permukaan dan erosi pada berbagai perlakuan mulsa vertikal

\begin{tabular}{lcc}
\hline Perlakuan & Aliran permukaan $\left(\mathrm{m}^{3} \mathrm{ha}^{-1}\right)$ & Tanah Tererosi $\left(\mathrm{Kg} \mathrm{ha}^{-1}\right)$ \\
\hline $\mathrm{P}_{0}=$ Kontrol & $466,68 \mathrm{a}$ & $2.255,5 \mathrm{a}$ \\
$\mathrm{P}_{1}=\begin{array}{l}\text { mulsa vertikal dengan } \\
\quad \text { panjang 1 m, lebar 0,5 } \mathrm{m}\end{array}$ & $108,19 \mathrm{~b}$ & $683,0 \mathrm{~b}$ \\
$\quad$ dan dalam 0,4 m & & \\
$\mathrm{P}_{2}=\begin{array}{l}\text { mulsa pertikal dengan } \\
\quad \text { panjang 1 m, lebar 0,5 } \mathrm{m} \\
\quad \text { dan dalam 0,5 m. }\end{array}$ & $317,55 \mathrm{ab}$ & $1062,9 \mathrm{ab}$ \\
\hline BNT 5\% & & 1312,2 \\
\hline KK (\%) & 244,81 & 43,4 \\
\hline Angka yang diikuti oleh huruf yang sama pada kolom yang sama menunjukkan tidak berbeda nyata pada uji BNT 5\%
\end{tabular}

Hasil uji lanjut terhadap rata-rata perlakuan menunjukkan bahwa perlakuan mulsa vertikal berpengaruh nyata terhadap aliran permukaan (Tabel 1). Perlakuan $\mathrm{P}_{1}$ menghasilkan aliran permukaan yang lebih rendah $\left(108,19 \mathrm{~m}^{3} \mathrm{ha}^{-1}\right)$ dibandingkan dengan perlakuan $\mathrm{P}_{0}$ $\left(466,68 \mathrm{~m}^{3} \mathrm{ha}^{-1}\right)$, namun tidak berbeda nyata dengan perlakuan $\mathrm{P}_{2}\left(317,55 \mathrm{~m}^{3} \mathrm{ha}^{-1}\right)$. Rendahnya aliran permukaan pada $\mathrm{P}_{1}$ disebabkan oleh banyaknya aliran air yang masuk ke dalam rorak mulsa vertikal, sehingga air hujan yang jatuh tidak langsung menjadi air larian yang membawa tanah tererosi (sedimen). Nurmi (2012) menjelaskan bahwa rendahnya aliran permukaan disebabkan oleh tingginya infiltrasi air ke dalam tanah akibat terciptanya biopori yang dapat meresapkan air dalam jumlah yang tinggi. Hasil penelitian Monde (2010) menunjukkan bahwa rorak yang diberi mulsa secara vertikal efektif menekan aliran permukaan hingga $73 \%$ dibandingkan dengan kontrol.

Hasil uji lanjut terhadap rata-rata perlakuan menunjukkan bahwa perlakuan mulsa vertikal berpengaruh nyata terhadap erosi (Tabel 1). Mulsa vertikal perlakuan $\mathrm{P}_{1}$ memiliki tigkat erosi yang lebih rendah $\left(683,0 \mathrm{Kg} \mathrm{ha}^{-1}\right)$, dibandingkan dengan perlakuan $\mathrm{P}_{0}(2255,5 \mathrm{Kg}$ $\left.\mathrm{ha}^{-1}\right)$, namun tidak berbeda nyata pada perlakuan $\mathrm{P}_{2}\left(1062,9 \mathrm{Kg} \mathrm{ha}^{-1}\right)$. Rendahnya erosi yang terjadi pada perlakuan $\mathrm{P}_{1}$ disebabkan karena sedikit aliran permukaan yang terjadi dan tertampung pada bak penampung aliran, karena aliran tersebut masuk ke dalam mulsa 
vertikal. Hal tersebut dijelaskan pula oleh Nurmi (2012) rendahnya erosi tanah disebabkan oleh rendahnya aliran permukaan dan sebagian tanah yang terangkut bersama AP terperangkap masuk ke dalam mulsa vertikal. Rendahnya aliran permukaan yang terjadi sebagai akibat tingginya infiltrasi air ke dalam tanah. Keefektifan mulsa vertikal menekan erosi juga dikarenakan oleh bangun rorak yang dibuat berjarak 3 meter. Jarak antar rorak mulsa vertikal sangat menentukan penekanan erosi tanah pada lahan kering berlereng. Sebagaimana dijelaskan oleh Brata (1998) dalam Monde (2010), mengemukakan bahwa semakin pendek jarak antar guludan/rorak pada lereng yang sama, semakin efektif menekan erosi dan aliran permukaan.

Korelasi yang ditunjukkan antara aliran permukaan dan erosi tanah ialah korelasi positif. Hasil analisis disajikan pada Gambar 1.

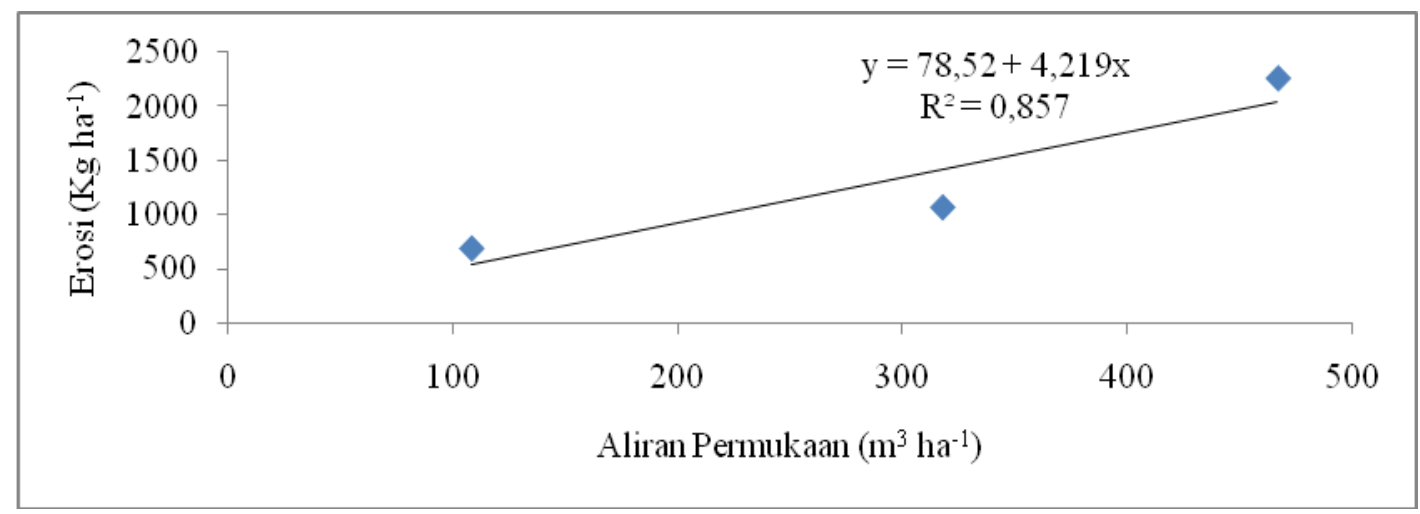

Gambar 1. Regresi antara aliran permukaan dengan erosi tanah

Aliran permukaan sangat berkaitan erat dengan erosi tanah yang terjadi. Hasil analisis regresi pada Gambar 1, menghasilkan persamaan regresi yaitu $y=78,52+4,219 x$ ini menunjukkan bahwa semakin meningkatnya aliran permukaan maka dibarengi pula dengan meningkatnya jumlah erosi yang terjadi. Setiap peningkatan aliran permukaan $1 \mathrm{~m}^{3} \mathrm{ha}^{-1}$ akan meningkatkan erosi sebesar 4,219 $\mathrm{kg} \mathrm{ha}^{-1}$. Bila erosi terjadi sangat tinggi melebihi erosi yang masih dapat ditoleransi maka sangat perlu dilakukan konservasi tanah dan air, sebaliknya rendahnya tingkat erosi yang terjadi menunjukkan semakin efektifnya mulsa vertikal. Besarnya nilai determinasi yang dihasilkan dari analisis regresi korelasi adalah $\mathrm{R}^{2}=0,857$. Hasil ini menunjukkan bahwa $85,7 \%$ erosi yang terjadi dipengaruhi oleh aliran permukaan, sedangkan $14,3 \%$ erosi yang terjadi dipengaruhi oleh faktor yang lain.

\section{Pertumbuhan Tanaman Jagung}

Analisis pertumbuhan tanaman jagung pada berbagai perlakuan mulsa vertikal dilakukan pada beberapa parameter yakni diameter batang dan jumlah daun. Berbagai perlakuan mulsa vertikal menunjukkan pengaruh yang berbeda pada berbagai parameter yang diamati. Data rata-rata pertumbuhan tanaman jagung dengan hasil uji lanjut $\mathrm{BNT}(\mathrm{P}<0,05)$ masing-masing parameter disajikan pada Tabel 2.

Tabel 2. Data rata-rata pertumbuhan tanaman jagung pada berbagai perlakuan mulsa vertikal

\begin{tabular}{|c|c|c|}
\hline Perlakuan & Diameter Batang $(\mathrm{cm})$ & Jumlah Daun (helai) \\
\hline $\mathrm{P}_{0}=$ Kontrol & $1,88 b$ & 10,8 \\
\hline $\begin{aligned} \mathrm{P}_{1}= & \text { mulsa vertikal dengan } \\
& \text { panjang } 1 \mathrm{~m}, \text { lebar } 0,5 \\
& \text { dan dalam } 0,4 \mathrm{~m}\end{aligned}$ & $2,21 \mathrm{a}$ & 11,1 \\
\hline $\begin{array}{l}\mathrm{P}_{2}=\text { mulsa pertikal dengan } \\
\text { panjang } 1 \mathrm{~m}, \text { lebar } 0,5 \mathrm{~m} \\
\text { dan dalam } 0,5 \mathrm{~m} .\end{array}$ & $2,10 \mathrm{a}$ & 10,9 \\
\hline BNT 5\% & 0,17 & \\
\hline KK (\%) & 3,58 & 2,1 \\
\hline
\end{tabular}


Hasil uji lanjut terhadap rata-rata perlakuan menunjukkan bahwa perlakuan mulsa vertikal berpengaruh nyata terhadap diameter batang tanaman jagung (Tabel 2). Perlakuan pada $\mathrm{P}_{1}$ menghasilkan rata-rata diameter batang yang lebih tinggi $(2,21 \mathrm{~cm})$, dibandingkan dengan perlakuan $\mathrm{P}_{0}(1,88 \mathrm{~cm})$, namun tidak berbeda nyata pada perlakuan $\mathrm{P}_{2}(2,10 \mathrm{~cm})$. Berpengaruhnya mulsa vertikal pada diameter batang jagung dipengaruhi oleh banyaknya air terperangkap pada rorak yang diserap tanaman sehingga dapat menambah lebar diameter batang tanaman jagung. Air yang terperangkap ke dalam rorak terinfiltrasi melalui lubanglubang kecil yang terbentuk akibat penambahan mulsa, sehingga berguna bagi tanaman.

Pada Tabel 2 menunjukkan bahwa perlakuan mulsa vertikal tidak berpengaruh nyata terhadap jumlah daun tanaman jagung. Perlakuan pada $\mathrm{P}_{1}$ menghasilkan rata-rata jumlah daun yang lebih banyak (11,1 helai), dibandingkan dengan perlakuan $\mathrm{P}_{2}$ (10,9 helai) dan $\mathrm{P}_{0}$ (10,8 helai). Tidak berpengaruhnya berbagai perlakuan ini disebabkan oleh mulsa vertikal belum menunjukkan pengaruh nyata pada pertumbuhan jumlah daun tanaman jagung, dan mungkin akan berpengaruh pada penanaman berikutnya. Demikian pula dijelaskan pada penelitian Murtilaksono et al., (2007) menunjukkan hasil penambahan jumlah pelepah baru rata-rata per pokok pohon kelapa sawit per dua minggu untuk setiap blok tidak menunjukkan perbedaan yang nyata yaitu 0,87-0,88 pelepah atau dapat dikatakan setiap dua minggu muncul satu pelepah baru per pokok tanaman sawit.

\section{Produksi tanaman jagung}

Produksi tanaman merupakan salah satu tolak ukur suatu komoditas tanaman pertanian berhasil dibudidayakan. Pada penelitian ini, parameter produksi yang diamati adalah berat seribu biji jagung dan berat pipilan jagung kering panen. Setiap perlakuan mulsa vertikal memberikan pengaruh yang berbeda pada produksi tanaman jagung. Data rat-rata produksi jagung disajikan pada Tabel 3.

Tabel 3. Data rata-rata berat seribu biji jagung (g) dan berat pipilan jagung kering panen (ton $\mathrm{ha}^{-1}$ ) pada berbagai perlakuan mulsa vertikal

\begin{tabular}{|c|c|c|}
\hline Perlakuan & Berat Seribu biji (g) & Berat Pipilan (ton ha' ${ }^{-1}$ ) \\
\hline $\mathrm{P}_{0}=$ Kontrol & 192,7 & $2,48 b$ \\
\hline $\begin{aligned} \mathrm{P}_{1}= & \text { mulsa vertikal dengan } \\
& \text { panjang } 1 \mathrm{~m}, \text { lebar } 0,5 \mathrm{~m} \\
& \text { dan dalam } 0,4 \mathrm{~m}\end{aligned}$ & 198,3 & $3,28 \mathrm{a}$ \\
\hline $\begin{aligned} \mathrm{P}_{2}= & \text { mulsa pertikal dengan } \\
& \text { panjang } 1 \mathrm{~m} \text {, lebar } 0,5 \mathrm{~m} \\
& \text { dan dalam } 0,5 \mathrm{~m} .\end{aligned}$ & 193,3 & $3,27 \mathrm{a}$ \\
\hline BNT 5\% & & 0,43 \\
\hline KK (\%) & 5,1 & 6,3 \\
\hline
\end{tabular}

Angka yang diikuti oleh hurufyang sama pada kolom yang sama menunjukkan tidak berbeda nyata pada uji BNT 5\%

Pada Tabel 3 menunjukkan bahwa perlakuan mulsa vertikal tidak berpengaruh nyata terhadap berat seribu biji jagung. Perlakuan pada $\mathrm{P}_{1}$ menghasilkan rata-rata berat seribu biji yang lebih tinggi (198,3 g), dibandingkan dengan perlakuan $\mathrm{P}_{2}(193,3 \mathrm{~g})$ dan $\mathrm{P}_{0}(192,7 \mathrm{~g})$. Tidak berpengaruhnya perlakuan mulsa vertikal diduga disebabkan oleh asupan air yang membawa unsur hara yang kurang diperoleh tanaman setelah terbentuknya tongkol jagung sehingga sebagian biji jagung yang terbentuk menjadi kurang bernas.

Hasil uji lanjut terhadap rata-rata perlakuan menunjukkan bahwa perlakuan mulsa vertikal berpengaruh nyata terhadap pipilan jagung (Tabel 3). Perlakuan $\mathrm{P}_{1}$ menghasilkan pipilan jagung yang lebih tinggi $\left(3,28\right.$ ton $\left.\mathrm{ha}^{-1}\right)$ dibandingkan dengan perlakuan $\mathrm{P}_{0}(2,48$ ton $\left.\mathrm{ha}^{-1}\right)$, namun tidak berbeda nyata dengan perlakuan $\mathrm{P}_{2}\left(3,27\right.$ ton $\left.\mathrm{ha}^{-1}\right)$. Tingginya hasil jagung pada perlakuan $\mathrm{P}_{1}$ disebabkan oleh berbagai perlakuan mulsa vertikal mampu menekan aliran permukaan dan erosi yang terjadi, sehingga kebutuhan air tanaman masih tersedia. Rendahnya 
aliran permukaan dan erosi serta tersedianya kebutuhan air dan unsur hara lainnya akan dapat meningkatkan produksi tanaman jagung.

Korelasi antara aliran permukaan dengan produksi tanaman jagung pada berbagai perlakuan mulsa vertikal disajikan pada Gambar 2.

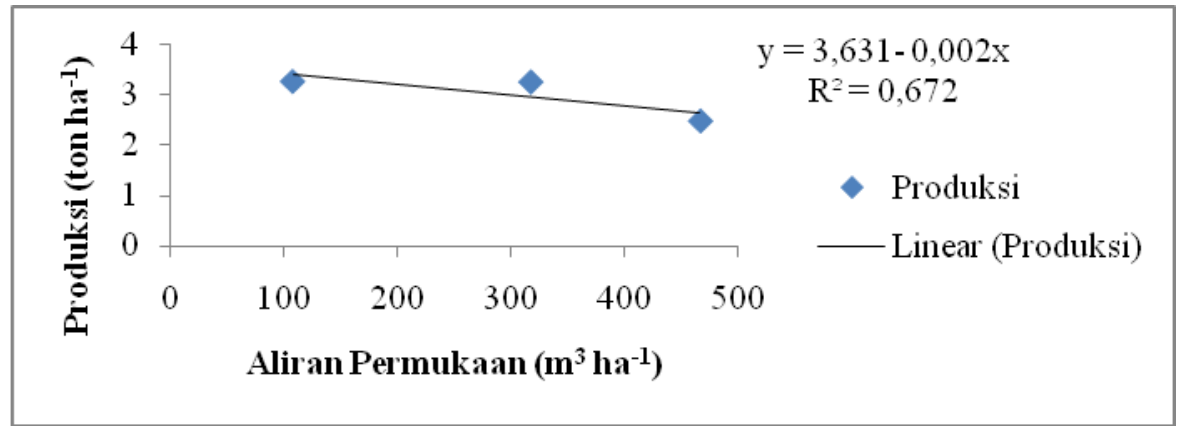

Gambar 2. Regresi antara aliran permukaan dengan produksi

Korelasi antara aliran permukaan dan peningkatan produksi menghasilkan persamaan regresi yaitu $\mathrm{y}=3,631-0,002 \mathrm{x}$ ini menunjukkan regresi korelasi yang negatif. Dapat dijelaskan bahwa semakin meningkatnya aliran permukaan maka produksi tanaman jagung semakin menurun, demikian juga sebaliknya semakin rendah aliran permukaan maka produksi tanaman jagung semakin meningkat. Setiap kenaikan aliran permukaan sebesar $1 \mathrm{~m}^{3} \mathrm{ha}^{-1}$ terjadi penurunan produksi jagung sebesar 0,002 ton ha- ${ }^{-1}$. Ini menunjukkan bahwa berbagai perlakuan mulsa vertikal berpengaruh terhadap penurunan aliran permukaan dan meningkatkan produksi tanaman. Besarnya nilai determinasi yang dihasilkan dari analisis regresi korelasi adalah $\mathrm{R}^{2}=0,672$. Hasil ini menunjukkan bahwa $67,2 \%$ penurunan produksi tanaman jagung dipengaruhi oleh aliran permukaan, sedangkan $32,8 \%$ penurunan produksi dipengaruhi oleh faktor lain.

Untuk melihat korelasi antara erosi dengan produksi pada berbagai perlakuan mulsa vertikal dilakukan dengan analisis regresi. Hasil analisis regresi disajikan pada Gambar 3. Regresi yang dihasilkan adalah linear negatif.

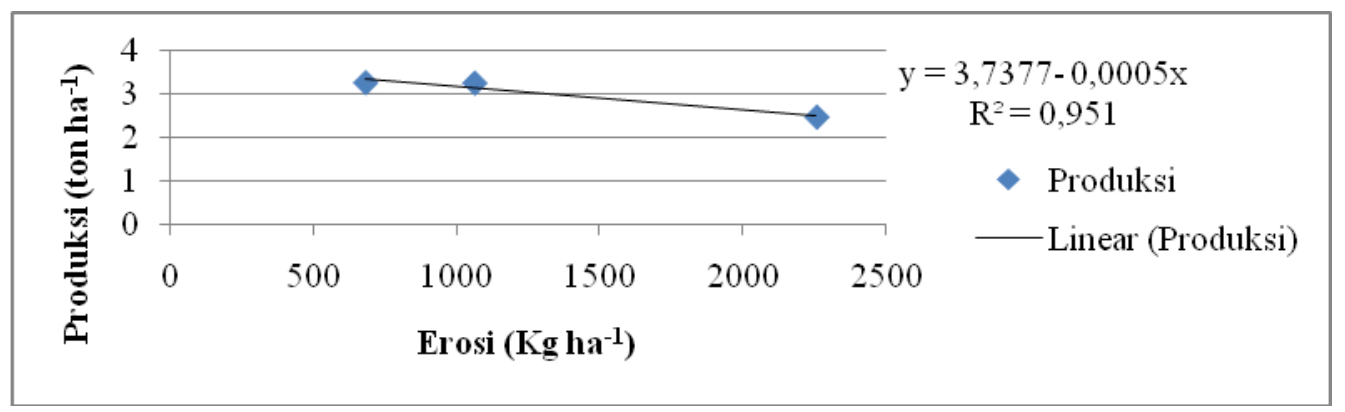

Gambar 3. Regresi antara erosi dengan produksi

Korelasi antara erosi dan peningkatan produksi menghasilkan persamaan regresi yaitu $\mathrm{y}=$ 3,7377 - 0,0005x ini menunjukkan regresi korelasi yang negatif. Dapat dijelaskan bahwa semakin meningkatnya erosi maka produksi tanaman jagung semakin menurun, demikian juga sebaliknya semakin rendah erosi maka produksi tanaman jagung semakin meningkat. Setiap kenaikan erosi sebesar $1 \mathrm{~kg} \mathrm{ha}^{-1}$ terjadi penurunan produksi jagung sebesar 0,0005 ton $\mathrm{ha}^{-1}$. Ini menunjukkan bahwa berbagai perlakuan mulsa vertikal berpengaruh terhadap penurunan erosi dan meningkatkan produksi tanaman. Besarnya nilai determinasi yang dihasilkan dari analisis regresi korelasi adalah $\mathrm{R}^{2}=0,951$. Hasil ini menunjukkan bahwa $95,1 \%$ penurunan produksi tanaman jagung dipengaruhi oleh erosi, sedangkan $4,9 \%$ penurunan produksi dipengaruhi oleh faktor lain. 


\section{KESIMPULAN}

1. Perlakuan mulsa vertikal $P_{1}$ dengan ukuran panjang $1 \mathrm{~m}$, lebar $0,5 \mathrm{~m}$ dan kedalaman $0,4 \mathrm{~m}$ menimbulkan aliran permukaan dan erosi tanah yang nyata lebih rendah (aliran permukaan $=108,19 \mathrm{~m}^{3} \mathrm{ha}^{-1}$ dan erosi $=683,0 \mathrm{~kg} \mathrm{ha}^{-1}$ ), dibandingkan dengan tanpa perlakuan mulsa vertikal $\left(\mathrm{P}_{0}\right)$, namun tidak berbeda nyata dengan perlakuan $\mathrm{P}_{2}$.

2. Perlakuan mulsa vertikal $P_{1}$ dengan ukuran panjang $1 \mathrm{~m}$, lebar $0,5 \mathrm{~m}$ dan kedalaman $0,4 \mathrm{~m}$ berpengaruh nyata terhadap pertumbuhan diameter batang jagung $(2,21 \mathrm{~cm})$ dan meningkatkan produksi pipilan jagung kering panen $(3,28$ ton ha-1).

3. Aliran permukaan berkorelasi positif dengan erosi serta aliran permukaan dan erosi berkorelasi negatif dengan produksi.

\section{DAFTAR PUSTAKA}

Abdurachman A, A Dariah dan A Mulyani. 2008. Strategi dan Teknologi Pengelolaan Lahan Kering Mendukung Pengadaan Pangan Nasional. Balai Besar Penelitian dan Pengembangan Sumberdaya Lahan Pertanian, Bogor. Jurnal Litbang Pertanian, 27(2) : 43-49.

Arsyad S. 2006. Konservasi Tanah dan Air. Bogor. IPB Press.

Badan Pusat Statistik (BPS). 2011. Gorontalo dalam Angka. Badan Pusat Statistik Provinsi Gorontalo. Gorontalo.

Brata KR. 2004. Modifikasi Sistem Microcatchment untuk Konservasi Tanah dan Air Pada Pertanian Lahan Kering. Departemen Ilmu Tanah, Fakultas Pertanian IPB Bogor.

Dariah A, A Rachman dan U Kurnia. 2004. Erosi dan Degradasi Lahan Kering di Indonesia. hlm : 1-9, dalam Teknologi Konservasi Tanah pada Lahan Kering Berlereng. Pusat Penelitian dan Pengembangan Tanah dan Agroklimat, Badan Penelitian dan Pengembangan Pertanian, Depertemen Pertanian, Bogor.

Hardiyatmo HC. 2006. Penanganan Tanah Longsor dan Erosi. Yogyakarta. Gadjah Mada University Press.

Murtilaksono K, ES Sutarta, NH Darlan, dan Sudarmo. 2007. Aplikasi Teras Gulud dan Rorak Bermulsa Vertikal dalam Upaya Peningkatan Produksi Kelapa Sawit. Departemen Ilmu Tanah dan Sumberdaya Lahan, Faperta, IPB dan Pusat Penelitian Kelapa Sawit (PPKS), Medan, hlm : 39-48.

Monde, A. 2010. Pengendalian Aliran Permukaan dan Erosi pada Lahan Berbasis Kakao di DAS Gumbasa, Sulawesi Tengah. Media Litbang Sulteng III (2) : $131-136$.

Noeralam A, S Arsyad dan A Iswandi. 2003. Teknik Pengendalian Aliran Permukaan Yang Efektif pada Usahatani Lahan Kering Berlereng. IPB Bogor. Jurnal Tanah dan Lingkungan, Vol. 5 No.1 : 13-16.

Nurmi. 2012. Nisbah pengkayaan sedimen dan erosi tanah Pada pertanaman jagung (Zea mays, L.). Laporan Penelitian. Jurusan Agroteknologi, Fakultas Ilmu-Ilmu Pertanian,Universitas Negeri Gorontalo, hlm : 1-42.

Pratiwi. 2001. Efektivitas Penempatan Mulsa Vertikal untuk Pengurangan Aliran Permukaan dan Sedimentasi serta Kehilangan Unsur Hara di Hutan Tanaman Mahoni Afrika(Khaya anthoteca), Pasir Awi-Lewiliang, Jawa Barat. Bul. Pen. Hutan (For. Res. Bull) $628: 49-60$.

Ruijter J dan F Agus. 2004. Mulsa: Cara Mudah untuk Konservasi Tanah. Pidra dan Word Agroforestry Centre Transforming Lives and Landscapes. http://www.worlda groforestrycentre.org/sea/Publications/files/leaflet/LE0023-04.pdf (13 Desember 2011).

Santoso D. 2003. Teknologi Pengelolaan Lahan Kering. Lokakarya Sistem Integrasi Kelapa Sawit-Sapi. Balai Penelitian Tanah, Pusat Penelitian dan Pengembangan Tanah dan Agroklimat. Bogor, hlm : 187-198. 
Subagyono K, U Haryati dan SH Tala'ohu. 2004. Teknologi Konservasi Air pada Pertanian Lahan Kering. hlm : 151-188, dalam Teknologi Konservasi Tanah pada Lahan Kering Berlereng. Pusat Penelitian dan Pengembangan Tanah dan Agroklimat, Badan Penelitian dan Pengembangan Pertanian, Depertemen Pertanian, Bogor.

Wibowo A, Y Lisnawati dan CNS Priyono. 2007. Praktek-Praktek Konservasi Tanah dan Air Pada Lahan Kritis (Practices of Soil and Water Conservation on Critical Lands). Pusat Litbang Hutan Tanaman Kampus Balitbang Kehutanan Bogor. Info Hutan Tanaman Vol.2 No.3 : 135-153. 